\title{
Cultural revitalization and the ontology of communicative spaces: 'Mobile coordinating' among Guaraní
}

Sarah Wagner, Open University of Catalonia, Barcelona

This is the accepted version of the following article.

Wagner, S. (2019). Cultural revitalization and the ontology of communicative spaces: 'Mobile coordinating' among Guaraní. International Journal of Cultural Studies, 22(3), 417-433.

The published version can be found at:

https://journals.sagepub.com/doi/full/10.1177/1367877918793429 


\title{
Cultural revitalization and the ontology of communicative spaces: 'Mobile coordinating' among Guaraní
}

\author{
Sarah Wagner, Open University of Catalonia, Spain
}

\begin{abstract}
Much ICT-related cultural revitalization research in indigenous contexts concerns the production and circulation of traditional and indigenous language content matter. Drawing on ethnographic research with Guaraní communities in Tarija Department, Bolivia, this article argues for the significance of everyday, intracommunity communicative spaces to cultural revitalization. I describe how Guaraní renegotiate and delimit ICT practices—with respect to changing group norms on appropriate communication mediums-to safeguard relaxed, responsive and face-to-face communicative spaces. In the context of this research, the sentiment of togetherness reinforced by such communicative spaces was what underlay and incited cultural practices. This opens up important issues for cultural revitalization research relating to the ontology of ICT-mediated communicative spaces and the processes through which these are renegotiated and decolonized.
\end{abstract}


In the early 2000s indigenous representatives around the world mobilized for inclusion in the so-called 'Information Society' and raised awareness that Information and Communication Technologies (ICTs) may not align with cultural aims. The president of the UN Permanent Forum on Indigenous Issues announced to the World Summit on the Information Society in Geneva that indigenous peoples 'do not seek inclusion at the expense of their rights, cultural identities, traditional territories or resources. It must be indigenous peoples themselves who decide on how and when they access and use new technologies' (qtd. in Brown and Tidwell Cullen, 2005).

Self-determination has been a key component of indigenous appropriations of communication technologies. Indigenous groups have obtained rights to radio and television frequencies (see Rodríguez, 2001; Bell, 2008; Wilson and Stewart, 2008; Magallanes-Blanco and Ramos Rodríguez, 2016) and launched their own websites (see Landzelius, 2006; Ginsburg, 2008; Ormond-Parker et al., 2013). Further instances of 'digital self-determination' (McMahon, 2011) include a collaborative online platform for software development in Quechua language (López-Vicent et al. 2014: 7-8), an alternative online radio streaming and video-sharing service (IRCA, 2016), and locally owned and managed mobile network services (Budka, 2015; Magallanes-Blanco and Rodríguez-Medina, 2016). Such initiatives reveal the felt need to rebalance inequalities relating to the production and ownership of technologies and services. Yet concerns about 'global' ICTs and 'local' cultural identities initially arose over the presumed homogenizing influences of foreign, 
audiovisual contents (Fejes, 1981; Morley and Robins, 1995:44). This legacy continues to influence development research and practice. ICT-related interventions targeting indigenous groups in Latin America (Villacrés Roca, 2016:112) and elsewhere (see Ormond-Parker et al., 2013; Dyson et al. 2016) often provide databases, applications or websites for the development and circulation of indigenous cultural contents.

Much indigenous media research has also concerned the nature of contents. Analyses on media representations of indigenous peoples and by indigenous peoples have been a mainstay of the field (Mccallum and Waller, 2017; see also Wilson and Stewart, 2008:3). In what Ginsburg et al. (2002:51) have termed a 'double set of possibilities', ICTs can be simultaneously subjugating and empowering for indigenous communities as they bring opportunities for self-representation alongside further infiltrations of dominant cultures. I maintain such possibilities not only relate to contents circulated by ICTs but also to ICTs' communicative architectures (see also Srinivasan, 2012).

Drawing on ethnographic research with Guaraní peoples residing near the town of Villamontes, southeast Bolivia, this article analyzes the position of ICT-mediated communication within cultural trajectories. Colonization brought significant cultural rupture among Guaraní, followed by cultural resurgences in recent years, with political and local interest in revitalizing Guaraní language and cultural practices. Mobile telephony service — the most used ICT among community members— has opened up new opportunities for intercommunity communication and political coordination. To 
understand the cultural positioning of this communication medium, I adopt a communicative ecology approach (Slater, 2013) and have concern with the whole of communication and information activities, their interrelations and their sociocultural framing.

Research on the interrelations of mobile technologies and culturally situated users is not new; rather, it has a long history, often drawing on concepts from science and technology studies to understand the mutual shaping of technical systems and social practices (see Castells et al., 2007). The way mobile communication practices emerge within social contexts has both transformed and reconfirmed long-term cultural values (cf. Lesitaokana, 2017; Tazanu and Frei, 2017). New media appropriations among indigenous peoples have recently gained some research traction, particularly relating to newfound opportunities for collective action and participation in public debates (Wilson, Carlson and Sciascia, 2017). Additionally, a small group of studies has examined indigenous peoples' renegotiations of mobile communication services, through which alternative communicative styles or codes of use have been co-produced (e.g. Kral, 2013; Kemper, 2016; Zapata, 2017).

In the present research with Guaraní communities, communicative practices played an integral role in cultural revitalization processes. Much cultural revitalization research concerning new media considers the extent to which traditional and indigenous language content matter is produced and circulated (e.g. Greyling and McNulty, 2011; SanNicolas- 
Rocca and Parrish, 2013; Villacrés Roca, 2016; see also Dyson et al., 2016). Meanwhile, website and database architectures have been found to devalue indigenous ways of knowing (Oppenneer, 2009; van Gelderen and Guthadjaka, 2017). This article contributes a new angle to such research by drawing attention to the significance of communicative spaces within indigenous cultural trajectories. This opens up important issues for cultural revitalization research relating to the ontology of ICT-mediated communicative spaces and the processes through which these are renegotiated and decolonized.

\section{Technical architectures and communicative spaces}

ICTs - the array of both digital and non-digital technologies used to store, process and communicate information-are understood in this article as interdependent and integrated within wider communicative, social and cultural practices (cf. Slater, 2013). Along with Salazar (2007), I am interested in way that the meanings, purposes and functions of ICTs arise through local appropriations and come into being within communities as 'a form of action' (1970). Analyses of ICT appropriation go beyond adoption research to understand the ways ICTs are renegotiated and reconfigured (de Souza e Silva et al., 2011; Sey, 2011) through what Bar et al. (2016) have called 'a contest for control over a technical system's configuration' (618). ICT appropriation is thus a political process, shaped by both technical affordances—or the material, relational or functional aspects of technologies that frame their possible uses and meanings (see Hutchby, 2001)—and the innovations, practices and norms of users and user groups. 
'Technical architectures' are a way of speaking about the spatial or structural organization of technical affordances (Papacharissi, 2009). A growing body of cultural revitalization research concerns the way website or database architectures interrelate with indigenous epistemologies and some practical-oriented studies have worked with indigenous groups to develop alternative technical architectures based on non-hierarchical or performative ways of knowing (Srinivasan, 2006, 2012; van Gelderen and Guthadjaka, 2017; Verran and Christie, 2007). In the present research, I find a spatial understanding of technical affordances relevant for analyses of communication practices, as among Guaraní in Villamontes the reproduction of relaxed, in-person and responsive communicative spaces holds an integral position in the struggle for cultural resurgence.

The concept of 'communicative spaces' has been used in community media studies to explore new opportunities for public voice among marginalized people (see Rodríguez, 2001; Spitulnik, 2017). The present research also concerns the cultural politics of 'communicative spaces' but in respect to everyday communication. My interest is in the way that everyday communication practices are re-structured through agents' digital choices and the positioning this has within efforts to maintain cultural continuity.

\section{The Guaraní in Southeast Bolivia}

Guaraní are recognized as the fourth largest indigenous group in Bolivia, largely residing in the three most eastern departments of Tarija, Chuquisaca and Santa Cruz. Guaraní peoples moved into the Andean foothills and lowland Chaco region in the $15^{\text {th }}$ and 
$16^{\text {th }}$ Century as part of wider processes of migration often conceptualized as the search for yvy marae, or 'the land without evil' (Saignes, 2007). The concept of yvy marae continues to play a role in Guaraní political discourse, and rather than referring to a geographic place, it points to a political or social ideal: 'the incessant search for the construction of a perfect society' (Asamblea del Pueblo Guaraní qtd. in Ruiz Fornier et al., 2013). ${ }^{1}$

The Asamblea del Pueblo Guaraní (APG)—composed of a network of national, departmental, zonal and community level assemblies—was formed in the late 1980s and represents Guaraní interests as distinct from the dominant Andean indigenous context. Its organizational structure reflects that of other indigenous unions but also derives from the Guaraní tradition of group decision-making in assemblies (Wahren, 2011). While early anthropological portrayals tended to over idealize a 'leader without power' in the Bolivian lowlands (Combès and Villar, 2004; Saignes, 2007), group discussion in assemblies is an ongoing practice (cf. Lowrey, 2011; Wahren, 2011) and the medium of choice for political practice in the APG.

The present research was situated in the municipality of Villamontes where Guaraní form an estimated seven percent of the population (INE, 2012; cf. Ruiz Fornier et al., 2013). At the time of research, 12 communities - hereafter referred to as 'Villamontes communities'—ranging from 14 to 115 families were registered with the Villamontes Zonal APG. The challenges faced by the communities varied greatly, from cultural 
marginalization for communities situated within larger villages to lack of basic infrastructure, for those located far from the main town of Villamontes.

\section{Methodology}

Research in indigenous contexts remains contentious. Smith's 1999 analysis of academia's colonizing role elucidated the oppression and misrepresentation of indigenous knowledges through Western research agendas. While there is much debate on best practices for decolonizing methodologies, close collaboration with indigenous representatives and community members is an important starting point (see Wingert and White, 2017).

The concept for the present research on ICT appropriations in Guaraní communities was developed in collaboration with the Departmental APG in Tarija and a non-profit organization—Communidad Estudios JAINA—which has a long history of providing technical support to the APG. This research project was situated within a longer period of ethnographic research which I conducted with Guaraní communicators, leaders and community members in Argentina and Bolivia from September 2013 to September 2014. Planning began in Tarija in December 2013. I worked alongside departmental leaders for a two-month period to develop the aims and procedures for the research in Villamontes. Research with Villamontes communities was carried out over a five-week period in July and August 2014. Villamontes community leaders and individual participants guided the research process in their communities, which for the most part entailed informal 
discussions in participants' backyards, alike much of Guaraní political and communicative practice.

Research was conducted in Spanish, the common language used in family homes and at assemblies. Participant observation in assemblies, community events and daily life formed an important part of the research. During visits to the 12 communities, I spent time casually talking to members and observing ICT use. Three community leaders expressed interest in carrying out the research through group discussion. With groups of 8 to 15 members, I opened up discussion on participants' communicative resources and networks (Hearn et al., 2009: 31) as well as their perspectives on ICT use and the loss/revitalization of Guaraní culture. In other communities, I invited members to participate in informal, open-ended interviews on these same themes; this resulted in a total of 34 interview participants -17 female and 17 male, spanning the ages of 8 to 70 years. Following the research period in Villamontes, five political and auxiliary members of the Departmental APG in Tarija participated in interviews in which they provided further insights on the themes arising in the community research.

A wide variety of data were collected from meetings, events, journeys, conversations, documents and interviews which were organized using Atlas.ti software. The analysis was developed through an iterative process carried on throughout the research period and combined methods of indexing and analytic accounts to contextually resituate findings (see Hammersley and Atkinson, 2007). 


\section{Cultural revitalization and communal living}

The Villamontes area underwent great upheaval and violence during the colonial years.

Through an onslaught of Christian missions, sugar cane plants and cattle ranches-and the 1930s Chaco War - many indigenous peoples were displaced or put in situations of forced labor (see Gordillo and Leguizamón, 2002). In Villamontes communities, many middleaged informants had experienced great rupture in their lives when they entered the public education system and were forbidden to speak their native language. Others never had the opportunity to learn Guaraní. A 48-year-old informant explained she was raised as a laborer on a foreign family's farm and was forbidden to see her parents until she was 15 years old. In another case, a 34-year-old informant's entire family had been in a situation of forced labor, which she described as follows:

The creole prohibited people to speak in Guaraní on their properties, and so it was prohibited that our parents taught us or spoke to us in Guaraní. And they were threatened! If they taught Guaraní, they would kill them. Before it was like that.

Among leaders and middle-aged or older community members in Villamontes, the resurgence of historical cultural practices was politically significant for overturning colonial legacies. As Alvarsson (2007) found in neighboring Weenhayek communities, long periods of acculturation invigorated a search for symbolic cultural meanings to recreate and revalorize indigenous identities. Revitalization efforts among Guaraní in Villamontes were not only about cultural displays at community fairs but moreover aimed to reintegrate 
valued practices—Guaraní language use, dance and communal living-into everyday life, with the focus on youth. Guaraní identity was often characterized as a form of knowledge or practice that can be lost and relearnt, particularly exhibited through language and dance. Informants expressed hopes that youth would introduce Guaraní language—and identityback into the communities. A 32-year-old woman explained, 'Things changed, everyone changed to Spanish but recently we are returning to be bilingual'. That school education was predominantly in Spanish generated much concern among informants.

When asked if she thought youth identified as Guaraní, a 34-year-old woman responded, 'Not completely, but now they are learning, little by little.' Dance plays an important role in the learning process, through its communal practice and emotional sentiment. A 68-year-old woman residing in a remote, Guaraní-only community explained, 'Our culture, we don't forget it, we dance all the time'. Guaraní dance and music were influenced by the Carnival celebration, which merged with the Guaraní annual harvest festival, the Arete, in the early $20^{\text {th }}$ century. In an attempt to order the 'primitive', 'noisy' and ‘drunken’ Arete, missionaries introduced new activities, dances and musical instruments, which became appropriated and recreated as Guaraní traditions. In the end, the joyful and communal character of Guaraní music resonated through the missionary-introduced instruments and activities (see Wálter Sánchez, 1998). The re-appropriation of these dances played an important role in the 'Guaranízation' of Carnival celebrations. 
In Villamontes communities, the Carnival was considered the most important moment for cultural expression as it brought together community members in dance and other group activities. The display of cultural practices has been an important strategy for indigenous communities to redefine and recreate cultural trajectories (Hirsch et al., 2006). In the present research, group-based activities were found to underpin these cultural displays. Informants spoke of the importance of working together and emphasized the communal characteristic of craft productions and other community labor practices.

Being united is integral to Guaraní cultural practice. A delegate with the Departmental APG explained,

Solidarity is the fundamental value among us Guaraní. Our customs and our identity always carry this as the highest value ...It is what we identify with, how we know ourselves and what incites our culture.

The concept of ñande reko, often translated as 'our culture' (Wahren, 2011: 304), takes on the meaning of unity or living well together, according to informants familiar with the term. The challenge for Villamontes communities today was to find restorative spaces in which they could foster communal lifestyles. In small and remote communities, whole families or secondary school students resided in another town during the week to be closer to schools. In large, mixed communities, Guaraní families were dispersed among campesino families and lacked influence on community schools. Furthermore, neighboring ranchers had overtaken communal lands and there were ongoing disputes. The lack of communal land, 
the separation of family members during the week, and the marginal position of Guaraní families within the public education system, created a challenging context for cultural revitalization.

Members of a remote community who resided closer to town during the week explained that they practiced a shared-labor system on weekends, traditionally called motiro (Wahren, 2011: 206). More than for its historic connection to Guaraní culture-informants in fact used the Quechuan term, minga — this practice held cultural significance because it was carried out when community members were united on weekends. From community members' perspective, moving back permanently would be essential for cultural revitalization because being together is what underlies Guaraní cultural practices. A 32year-old woman explained,

We need to save our culture, live it and practice it here [in the community] to give value to our community. Because if I leave this place and I am there [living closer to town] and practice [our culture] there, in this, I have to abandon $u s$, and this doesn't work for us, it is not good.

The present research found that the value and force of Guaraní cultural practices arose from the communal characteristic of their production. The public display of traditional practices — ways of dress or corn-based food products—was promoted by leaders, and on one level, carried political significance by confronting what was previously prohibited. Yet, for many community members, the significance of cultural practices was 
not first and foremost related to historical context. What seemed paramount was how these practices were produced and performed in the present. Community togetherness and unity is what can transform new behaviors, actions and materials—dances, foods, festival celebrations, daily habits-into Guaraní practices.

\section{ICTs and cultural change}

As indigenous people we don't want to be like we were in the past, we want to change our lives, our culture and access new technologies... The Guaraní always want change. I think in respect to all of this, the new technologies, I think the Guarani people are asking for change. (32-year-old male informant)

Guaraní peoples in Bolivia lowlands have a long history of cultural hybridizations and social change (see Wálter Sánchez, 1998; Combes and Lowrey, 2006). Early anthropology in the region-influenced by Wissler's 1917 categorizations in The American Indianreinforced the objectification and discrimination of indigenous peoples (cf. Murdock, 1951). The ongoing imaginary of indigenous peoples as unchanging, traditional or exotic has shaped expectations for expressions of indigeneity (de la Cadena and Starn, 2007:9); likewise, in much development-oriented research, the demonstration and preservation of traditional knowledge is often the presumed cultural aim (e.g. SanNicolas-Rocca and Parrish, 2013; Owiny et al., 2014). Yet the diverse aims and activities of indigenous peoples with respect to their histories and contemporary situation cannot be overemphasized (de la Cadena and Starn, 2007; Ginsburg, 2008). 
In the present research with Villamontes communities, the shifting context of lifestyles and cultural practices formed part of informants' own imaginaries of traditional Guaraní culture, guided by the incessant search for yvy marae. Along these lines, the sociocultural changes supported by new communication technologies were envisioned as an opportunity within the ongoing cultural trajectory of the Guaraní. This is not to say that ICTs were welcomed in all aspects of life. As will be seen, ICT use was generally delimited to the realms of information gathering/sharing, cultural representation and coordination.

Inter-community communications in the Villamontes Zone have changed significantly during the past decade. A 32-year-old woman explained,

The only kind of communication we had was sending a person on a donkey or a horse... and this is how one would inform the others of a child's illness or whatever it was that was needed.....and now, at least it is facilitated a bit more, because before it wasn't practical.

Shortwave radio was the first ICT adopted in communities, used in schools and health stations. A non-profit organization began transmitting an AM signal from Tarija in the 1980s, and at the time of research, FM signals broadcasted from Villamontes town could be picked up in most communities. Television had become popular within the previous decade and was present in nearly all households on the electric grid. Media flowed into the communities from Santa Cruz based television stations and commercial radio stations in Villamontes. While some informants were concerned about the cultural influences of 
external media and, particularly, the introduction of new musical styles, many informants recounted the ways in which ICTs have supported cultural resurgence.

A fifty-year-old community representative who grew up in Tarija explained he learnt of his Guaraní heritage through awareness raised on radio programs. He explained,

When I came here... I hadn't heard about this, of speaking Guaraní, but then after, some years later, they started to speak on the radio, and this started to wake up the people and make them realize they are going to move ahead again.

While none of the communities had their own radio station, one woman presented a biweekly radio show where she spoke both Guaraní and Spanish. The main aim of the program in her opinion was to bring awareness to injustices in the communities, such as breaches of indigenous lands or workers' rights, and to strengthen Guaraní culture. Apart from this show, commercial radio stations charged a fee for announcements and messages. Informants felt a community radio station would be useful for reconnecting the communities, bringing people together, facilitating sharing about activities and/or promoting Guaraní language learning. A 38-year-old man explained,

I think that in order to know our origin, our culture, our way of thinking, we need a radio that is directly Guaraní, as now we can't express this, and there are many things to inform each other about and we have to carry on with little information. 
While most secondary schools had computers, only one community had a functioning internet center. Parents frequently paid public transport fares for their children to complete school assignments at internet centers in Villamontes town. While Facebook was actively used among departmental and national Guaraní leaders, in the present research only a few secondary school students residing in a community near Villamontes town had Facebook accounts. Other than secondary school students and a few men in their 20s and 30s who occasionally visited internet centers, informants had never used computers or the internet. This reflected the limited internet access in the communities as well as the lack of motivation among many adults to learn digital skills. Yet, adults were keen for youth to develop computer literacy. An informant in his late 60s explained, 'The kids... need to learn how to make a paper really quickly. This is important! This is what we need.'

Computer literacy was not only connected to employability, but also to the wider social and cultural development of the community. Informants who had never used the internet conceptualized it as a tool for finding information, in line with the assignments students were given at school. The internet provided a new information source that they did not want to be excluded from. A 22-year-old woman who had never used the internet explained, 'The good thing [about the internet] is that the youth can do some research there. They can look for things on the internet and then bring them here, and this is an advantage'. Informants of all ages supported augmenting the use of ICTs—such as word processing software, internet search engines and radio programming-for informational 
purposes, which included finding information on social and political activities outside communities as well as processing and sharing information between communities.

ICTs were also valued for cultural representation. Mass media representations of cultural fairs were welcomed; they amplified the reach of cultural displays. The act of recording and disseminating expressions of cultural identities, such as dancing, was not seen to influence the sentiment attached to the practice in the moment. Such recordings could be openly shared (cf. Gumbula et al. 2013; Leopold, 2013).

Meanwhile, the broadcasting of assemblies was not welcomed. In-person communication was valued and considered integral to uniting people for political practice. A 64-year-old community leader explained, 'If you put the meeting on the radio, you don't know if people are listening, you wouldn't know anything about that, and that would be a problem.' A delegate of the Departmental APG explained,

We cannot have a meeting over the radio, or telephone, this would be impossible. ...To make decisions, in any case, you need to be present! ...When we are in front of each other we meet, and we discuss in front of each other to make decisions.

Community assemblies were held in leaders' backyards in a circular arrangement. While the leader initiated the meeting and introduced issues, community members raised their own issues. Listening and allowing time for response was important (see also Lowrey, 2011). 
Informants in a group discussion described learning of the zonal assembly's plans inperson: 'They only use the phone to say they have information. They always come here and put out a call for a meeting'. The imparting of political information requires providing opportunities for others to respond face-to-face, as is the practice in assemblies.

Departmental leaders stationed in Tarija regularly drove the 7-hour journey to meet with delegates in communities of the zonal assemblies. This journey was considered necessary when information about political advancements or the subject matter of an upcoming meeting needed to be communicated. In these cases, in-person communication was expected because the information to be imparted formed part of an ongoing political process. An auxiliary member of the Departmental APG explained, 'The phone is to coordinate, to set the time, the date, so that we can meet in person, directly, at meetings. ...You cannot talk about something important over the phone'.

\section{Mobiles and mobilities}

Mobile telephony service arrived in most communities within five years of the research period, around the same time as public transport. The national telecommunications provider, Entel, offered the most expansive coverage with $2 \mathrm{G}$ service in two communities and $3 \mathrm{G}$ service in seven communities. In the three communities with limited or no mobile coverage, all households consulted owned at least one mobile. In these cases, the mobile was used when travelling to other communities or from nearby hill tops and other known places with signal. Five communities were without health centers and three were without 
public transport. In addition, many families were disunited, with members residing away during the week for secondary school or work. Mobiles were particularly valued for coordinating meetings, facilitating transport, calling for assistance in emergencies and contacting family members who resided in another locale.

In the short time since mobile services were made available in communities, they had become considered a basic need, essential for social well-being. However, mobile use was delimited to certain spheres of communication. Community members were presented with an array of mediums to facilitate communication, which mobile services formed part of: long voice calls, short voice calls, text messages, in-person meetings, public transport, taxi hire and letters. The way community members shifted between these mediums not only reflected individual choice but also a group dynamic in the appropriation of communication services, which resulted in social norms of use (see also Rennie et al, 2016). Group expectations on the use of communication mediums reflected the value attached to in-person communication, the relative cost of available services, as well as speed and ease.

The role of mobiles in political practices exhibits the relation between group expectations and communication medium choice. Community assemblies were communicated by the vocal through door-to-door notices, which leaders felt was the best way to ensure attendance. This aligned with general expectations of in-person communication within communities: mobiles were almost never used, as dropping-by unannounced was common practice. Yet in the coordination of zonal and departmental 
assemblies, mobiles played an important role. Community leaders connected regularly with other delegates through short calls and texts to arrange meeting points. They often made or received calls for organizational purposes during assemblies. Assemblies had a relaxed atmosphere, filled with joking and teasing, and rather than being disruptive, mobile use seemed to confirm the unrushed mood.

Coordinating by mobile phone_-faster, easier and cheaper than ground transport— was integrated within and facilitated highly valued practices of in-person communication. The coordination of work and family activities has been an important use for mobile telephony in many contexts around the world (Castells et al., 2006). What was of interest among Guaraní in Villamontes was the characterization of mobile-mediated coordinating not as communicating. Without allowing appropriate opportunity for response-which presupposed meeting in-person-communication would lose its value. A departmental delegate explained, 'The value that we give to speaking cannot be granted over the phone, so it is better to communicate, and go communicating'.

Communication beyond the community was increasingly important as political and family spheres distended geographically. While internal community communication remained in-person, external communication practices shifted as new transport options and mobile services were negotiated. Social norms, however, continued to prioritize closeness in communication. A departmental delegate explained, 
Communication comes from the family, and then after that, the community. If I want to pass on our history to my children... it has to involve communication that is very close... If there is not this kind of close communication, there would be no transmission of understanding.

Public transport expenses meant those residing at significant distances for workoften Santa Cruz or Tarija—did not see family members in the communities for months at a time. In a few households, texting or 'beeping' (Donner, 2007) was used to coordinate a longer call from a landline telephone in the city back to a mobile in the community. While this opportunity for communication was welcomed it also generated feelings of discomfort. A 32-year-old man who previously lived in Santa Cruz explained,

When you are on the phone you don't know what they are speaking of really, whereas if you are here, united, it is different. ...If there is a problem, you don't know in what state the other one is, and you don't know if they are fine or not.

While this informant appreciated the speed at which people can communicate using mobiles, being 'united' was invaluable for communication. Alongside mobiles, he considered public transport important for facilitating faster communication because it enabled 'more access to have a conversation over there [in another community]'.

The way individuals shifted between texts, voice calls and public transport revealed their communicative intent and the value they attached to the communication (see Madianou and Miller, 2013). Short voice calls and texting were the most common form of 
mobile communication among family and friends residing in different communities. These short forms of mobile-mediated communication were intertwined with longer conversations held in person, facilitated by public transport or taxi. That mobiles can facilitate ongoing contact throughout the day has generated sentiments of co-presence in other contexts (Castells et al., 2006:152; Madianou, 2016). Among Guaraní in Villamontes, mobiles were considered a means for in-person communication; short updates were valued but also infrequent and intertwined with travel. This not only reflected the limited array and cost burden of mobile services but also the sentiment of disunity that was attached to mobile-mediated communication—often characterized as 'non-communication'.

The only mobile service provider in many communities, Entel, billed clients by the minute rather than the second, which made texting popular. Texting in indigenous languages in other contexts has been important for local renegotiations of mobile communication (see Dyson et al. 2016; Zapata, 2017). In Villamontes communities, texting was always in Spanish—including among those who regularly voice called in Guaraní-as writing in Guaraní was not common practice. A 38-year-old woman who relied on predictive text for texting in Spanish lamented this service was not available in Guaraní.

Most mobiles used in Villamontes communities were basic brick or flip phones, which meant limited adaptability to available services. Mobile internet had not been used among informants, including those with internet-enabled feature phones. While internet use was rare in the communities, mobile data storage and sharing were practiced 
particularly among young men. Informants who had been to internet centers explained that they connected their mobiles to the computer to download data-games, ringtones, documents — and then shared data with others using Bluetooth or memory cards. A 32year-old man who only had accessed the internet by proxy explained, 'I don't know what page they enter, I say, "Can you get me that?" and then they get it for me'. While this informant had been pressured by friends in Villamontes town to use online messaging services, such as WhatsApp, he was not interested in expanding messaging or data-sharing options with those he could easily meet in-person.

Among those who had never accessed the internet, feature phones provided the opportunity to store and share internet-based resources for study and entertainment purposes. That community members were reluctant to engage with online data-sharing I suggest not only reflects the lacking mobile internet culture but also expectations and preferences for sharing information in-person. At the time of research, community internet centers were underway in two communities as part of the national government's internet expansion planning following the launch of the Tupac Katari satellite in 2013. New opportunities for internet use within communities will undoubtedly play a role in communication medium choices and in turn shift expectations and values attached to communication practices. This article analyzed community members' renegotiations of available mediums at a particular time, which reflected interests in protecting a certain ontology of communicative spaces — unrushed, relaxed, responsive, and face-to-face- 
particularly in the case of family and political communication. Along these lines, mobiles were most used for coordination and short updates. However, network services put short calls at a cost disadvantage, meaning texting in Spanish was a common choice among those who customarily communicated in Guaraní.

\section{Conclusion}

In the wake of the plurinational state (see Howard, 2010) and the quickly advancing 'information society,' youth in Villamontes communities were allotted the responsibility of leading the Guaraní forward in their struggle for cultural revitalization and social and political autonomy. Communication technologies presented new opportunities, potentially taking them closer to the yvy marae, or the better life. While discourses of pluriculturalism were rampant in Bolivia, community members were challenged to find restorative spaces to engage in cultural practices. Due to employment and education responsibilities, land takeovers and underservicing in rural areas, communities and families were being pulled apart; yet, group solidarity was considered integral for cultural resurgence.

Drawing on Alvarsson's (2007) differentiation between symbolic representations and underlying cultural continuity, the position of ICTs within cultural revitalization processes in Villamontes communities can be understood on two levels. On one level, ICTs supported members to showcase and share expressions of cultural identities. The symbolic representation of these expressions via media outlets played a role in extra-community politics by creating awareness, engaging more members and defying what had been 
prohibited. On the second level, ICTs were being renegotiated so that the communicative practices they instantiated supported the cultural continuity of 'close' communication. Opportunities for remote conversation and data-transfer were resisted when related to ongoing activities within communities. In-person communication was prioritized and intertwined with values of unity as well as the creation of relaxed communicative spaces thick with teasing.

Instances of ICT non-use in Villamontes communities were not only revealing of individual preferences or economic restraints but also group norms on communicative practices and the suitability of mediums (Madianou and Miller, 2013). In other indigenous contexts, ingroup restrictions have been placed on recording and disseminating traditional practices and cultural events to protect their cultural value (Gumbula et al., 2013; Leopold, 2013). For Guaraní in Villamontes, what needed management—and contained significant cultural value-were everyday cultural practices and the close forms of communication these entailed. Cultural identities were described in relation to ways of acting, and in particular, the underlying togetherness of group activities. Along these lines, political processes and family communication carried significant value and their practice was guided through shifting expectations on appropriate mediums.

Community members had largely redefined the mobile phone as a coordination device, and in doing so, reconfirmed the cultural values attached to in-person communication and group solidarity. Yet this process was not entirely supported by available mobile services, 
which offered neither per-second billing nor Guaraní predictive text. While users in diverse cultural localities have appropriated and redefined communication technologies (de Souza e Silva et al., 2011; Bar et al., 2016), ICT service architectures have a part in shaping or even streamlining communicative practices (Napoli and Obar, 2014). Both the capacity of users to redefine ICTs and the capacity of ICTs to be redefined are important to support performative and culturally relevant uses of ICTs (see Rodríguez et al., 2014:161).

While ICT-related cultural revitalization research has focused on the cultural orientation of contents (Greyling and McNulty, 2011; SanNicolas-Rocca and Parrish, 2013; Villacrés Roca, 2016; see also Dyson et al. 2016) and, to a lesser extent, indigenous knowledge practices (Oppenneer, 2009; Srinivasan, 2006; van Gelderen and Guthadjaka, 2017), this article draws attention to the cultural significance of everyday, intracommunity communicative practices. In Villamontes communities, the harmonization of ICT architectures with indigenous ways of communicating would support local efforts in cultural revitalization. Indigenous groups elsewhere have worked towards obtaining sovereignty over internet and mobile services when market-based services have not aligned with local needs and wants (McMahon, 2011; Budka, 2015). Furthermore, innovative appropriations by users at the 'bottom-of-the-pyramid' have influenced commercially developed services, particularly where policy contexts favor inclusive innovation (Foster and Heeks, 2016). In the minority Guaraní context of Villamontes, ICT service provision 
was another mode of marginalization, in which they lacked influence on what, when and how communication services became available in their communities.

The rapidly changing indigenous media landscape, fostering new opportunities for self-representation and ingroup communication, requires research perspectives that go beyond analyses of mass media representations (see Mccallum and Waller, 2017). This article has argued for the relevance of grounded, community-based research on everyday renegotiations of ICTs and shown the significance such renegotiations can have in revealing cultural concerns over the ontology of communicative spaces.

While the present analysis is contextually specific, the findings contribute to growing evidence on the cultural biases of technical architectures (Verran and Christie, 2007; van Gelderen and Guthadjaka, 2017) and the circumstances underlying indigenous takeovers of communication services (McMahon, 2011; Budka, 2015). Indigenous media research, thus, has concerns far beyond the nature of media contents. Important areas for further research could be the local conditions that support adaptability in the appropriation of ICT services, or favorable policy contexts for indigenous representation in ICT service planning (see also Couldry et al., 2017).

\section{Notes}

1 All translations from Spanish are the author's. 


\section{References}

Alvarsson J (2007) The process of ethno(re)genesis among the 'Weenhayek of the Gran Chaco (1976-2006). Revista del CESLA 10:139-156.

Bar F, Weber MS and Pisani F (2016) Mobile technology appropriation in a distant mirror: Baroquization, creolization, and cannibalism. New Media and Society 18(4):617-636.

Bell W (2008) A Remote Possibility: The Battle for Imparja Television. Alice Springs: IAD Press.

Brown J and Tidwell Cullen T (2005) Indigenous peoples at the World Summit on the Information Society. Cultural Survival 29(2). Available at: https://www.culturalsurvival.org/publications/cultural-survival-quarterly/indigenouspeoples-world-summit-information-society (accessed 4 January 2018).

Budka P (2015) From marginalization to self-determined participation: Indigenous digital infrastructures and technology appropriation in northwestern Ontario's remote communities. Journal des Anthropologues 142-143:127-153.

Castells M et al. (2007) Mobile Communication and Society: A Global Perspective. Cambridge: MIT Press.

Combès I and Lowrey K (2006) Slaves without masters? Arawakan dynasties among the Chiriguano (Bolivian Chaco, Sixteenth to Twentieth Centuries), Ethnohistory 53(4):689714. 
Combès I and Villar D (2004) Aristocracias Chané. 'Casas' en el Chaco Argentino y Boliviano, Journal de la Société des Américanistes. 90(2): 63-102.

Couldry N et al. (2017) Media and Communications. In: International Panel on Social Progress. Available at: https://www.ipsp.org/download/chapter-13 (accessed 28 April 2018) de la Cadena M. and Starn O (eds) (2007) Indigneous Experience Today. Oxford: Berg. de Souza e Silva A et al. (2011) Mobile phone appropriation in the favelas of Rio de Janeiro, Brazil, New Media and Society 13(3):411-426.

Donner J (2007) The rules of beeping: Exchanging messages via intentional 'missed calls' on mobile phones. Journal of Computer-Mediated Communication 13(1):1-22.

Dyson LE, Grant S and Hendriks M (eds) (2016) Indigenous People and Mobile Technologies. New York: Routledge.

Fejes F (1981) Media imperialism: an assessment. Media, Culture and Society 3(3):281-289.

Foster C and Heeks R (2016) Drivers of inclusive innovation in developing country markets: A policy perspective. In: Agola NO and Hunter A (eds) Inclusive Innovation for Sustainable Development. London: Palgrave Macmillan, pp.57-74.

Ginsburg F (2008) Rethinking the Digital Age. In: Wilson P and Stewart M (eds) Global Indigenous Media: Cultures, Poetics and Politics. Atlanta: Duke University Press, pp.127-144. 
Ginsburg F, Abu-Lughod L and Larkin B (eds) (2002) Media Worlds. Los Angeles: University of California Press.

Gordillo G and Leguizamón JM (2002) El Río y la Frontera: Movilizaciones Aborígenes, Obras Públicas y MERCOSUR en el Pilcomayo. Buenos Aires: Editorial Biblos.

Greyling E. and McNulty N (2011) The number in my pocket: The power of mobile technology for the exchange of indigenous knowledge. Knowledge Management for Development Journal 7(3):256-273.

Gumbula J, Corn A and Mant J (2013) Discovering the earliest shadows: A Yolnu-led approach to managing community access to archived cultural resources. In: OrmondParker L et al. (eds) Information Technology and Indigenous Communities. Canberra: AIATSIS, pp.197-206.

Hammersley M and Atkinson P (2007) Ethnography: Principles in Practice. London: Routledge.

Hearn G et al. (2009) Action Research and New Media. Cresskill: Hampton Press.

Hirsch S, González H and Ciccone F (2006) Lengua e identidad: ideologías lingüísticas, pérdida y revitalización de la lengua entre los tapietes. Indiana 23:103-122.

Howard R (2010) Language, signs, and the performance of power: The discursive struggle over decolonization in the Bolivia of Evo Morales. Latin American Perspectives 37(3):176194. 
Hutchby I (2001) Technologies, texts and affordances. Sociology 35(2): 441-456.

INE (2012) Censo nacional de población y vivienda. Available at: http://datos.ine.gob.bo/binbol/RpWebEngine.exe/Portal?BASE=CPV2012COM\&lan g=ESP (accessed 06 February 2018)

IRCA (2016) Indigitube. Available at: http://indigitube.com.au/ (accessed 18 February 2017).

Kemper KR (2016) Cultural hybridity, Resilience and the communication of contemporary Cherokee culture through mobile technologies. In: Dyson LE et al. (eds) Indigenous People and Mobile Technologies. New York: Routledge, pp.239-252.

Kral I (2013) The acquisition of media as cultural practice: Remote indigenous youth and new digital technologies. In: Ormond-Parker L et al. (eds) Information Technology and Indigenous Communities. Canberra: AIATSIS, pp.53-74.

Landzelius K (ed) (2006) Native on the Net: Indigenous and Diasporic Peoples in the Virtual Age. London: Routledge.

Lesitaokana, WO (2017) Mobile phone use in intimate relationships: The case of youth in Botswana. International Journal of Cultural Studies. Epub ahead of print 1 February 2017. DOI: $10.1177 / 1367877917694094$. 
Leopold R (2013) Articulating culturally sensitive knowledge online: A Cherokee case study. Museum Anthropology Review 7(1-2):85-104.

López-Vicent P, Sánchez-Vera M and Solano-Fernández IM (2014) Las TIC para el desarrollo de la identidad digital y cultural de pueblos originarios. Papelas de Trabajo sobre Cultura, Educación y Desarrollo Humano 10(1):1-18.

Lowrey K (2011) Ethics, politics, and host space: A comparative case study from the South American Chaco. Comparative Studies in Society and History 53(4):882-913.

McCallum K. and Waller L (2017) Indigenous media studies in Australia: Traditions, theories and contemporary practices. In: Minorities and Media: Producers, Industries, Audiences. London: Palgrave Macmillan, pp.105-124.

McMahon R (2011) The institutional development of indigenous broadband infrastructure in Canada and the United States: Two paths to 'digital self-determination'. Canadian Journal of Communication 36:115-140.

Morley D and Robins K (1995) Spaces of Identity: Global Media, Electronic Landscapes and Cultural Boundaries. New York: Routledge.

Madianou M (2016) Ambient co-presence: Transnational family practices in polymedia environments. Global Networks 16(2):183-201. 
Madianou M and Miller D (2013) Polymedia: Towards a new theory of digital media in interpersonal communication. International Journal of Cultural Studies 16(2):169-187.

Magallanes-Blanco C and Ramos Rodríguez JM (eds) (2016) Miradas propias: Pueblos Indigenas, Comunicación y Medios en la Sociedad Global. Quito: CIESPAL.

Magallanes-Blanco C and Rodríguez-Medina L (2016) Give me a mobile and I will raise a community. In: Robinson L et al. (eds) Communication and Information Technologies Annual. Emerald Group Publishing Limited, pp.315-343.

Murdock GP (1951) South American Culture Areas. Southwestern Journal of Anthropology 7(4):415-436

Napoli PM and Obar JA (2014) The emerging mobile internet underclass: A critique of mobile internet access. The Information Society 30(5):323-334.

Oppenneer M (2009) Using ICTs for indigenous cultural preservation: Challenges and strategies. Ethnos Project. Available at: http://www.ethnosproject.org/using-icts-forindigenous-cultural-preservation/ (accessed 19 January 2017).

Ormond-Parker L et al. (eds) (2013) Information Technology and Indigenous Communities. Canberra: AIATSIS. 
Owiny SA, Mehta K and Maretzki AN (2014) The use of social media technologies to create, preserve, and disseminate indigenous knowledge and skills to communities in East Africa', International Journal of Communication 8:234-247.

Papacharissi Z (2009) The virtual geographies of social networks: a comparative analysis of Facebook, LinkedIn and ASmallWorld. New Media amd Society, 11(1-2):199-220.

Rennie E et al. (2016) Internet on the Outstation: The Digital Divide and Remote Aboriginal Communities. Amsterdam: Institute of Network Cultures.

Rodriguez C (2001) Fissures in the Mediascape: an International Study of Citizens' Media. Cresskill: Hampton Press.

Rodríguez C, Ferron B and Shamas K (2014) Four challenges in the field of alternative, radical and citizens' media research. Media, Culture and Society 36(2):150-166.

Ruiz Fornier H, Buitendijk L and Valeroso Cuéllar Q (2013) Autonomía indígena en el Chaco Tarijeño: Los desafíos en el municipio de Yacuiba. Tarija: Comunidad de Estudios JAINA.

Saignes T (2007) Historia del Pueblo Chiriguano. La Paz: IFEA.

Salazar JF (2007) Indigenous peoples and the cultural construction of ICT in Latin America. In: Dyson LE et al. (eds) Information Technology and Indigenous People. Hershey: Information Science Publishing, pp.1966-1975. 
SanNicolas-Rocca T and Parrish J (2013) Using social media to capture and convey cultural knowledge: A case of Chamorro people. In: 46th Hawaii International Conference on System Sciences. Wailea, 7-10 January 2013, pp.3386-3395.

Sey A (2011) 'We use it different, different': Making sense of trends in mobile phone use in Ghana. New Media and Society 13(3):375-390.

Slater D (2013) New Media, Development and Globalization. Cambridge: Polity Press.

Smith LT (1999) Decolonizing Methodologies: Research and Indigenous Peoples. London: Zed Books.

Spitulnik D (2017) Alternative small media and communicative spaces. In: Hyden G et al. (eds) Media and Democracy in Africa. New York: Routledge.

Srinivasan R (2006) Indigenous, ethnic and cultural articulations of new media. International Journal of Cultural Studies 9(4):497-518.

Srinivasan R (2012) Re-thinking the cultural codes of new media: The question concerning ontology. New Media and Society 15(2):203-223.

Tazanu PM and Frei BA (2017) Closeness, distance and disappearances in Cameroonian mediated transnational social ties: Uses of mobile phones and narratives of transformed identities. Journal of African Media Studies 9(1):77-90. 
van Gelderen B and Guthadjaka K (2017) The Warramiri website: Applying an alternative Yolyu epistemology to digital development. Research and Practice in Technology Enhanced Learning 12(14):1-19.

Verran H and Christie M (2007) Using/designing digital technologies of representation in aboriginal Australian knowledge practices. Human Technology 3(2):214-227.

Villacrés Roca JR (2016) Incidencia del uso de las Tecnologías de Información y Comunicación (TIC) en los hábitos y costumbres de jóvenes de cultura kichwa en Ecuador. Asian Journal of Latin American Studies 29(1):109-131.

Wahren J (2011) Movimientos Sociales y Disputas por el Territorio y los Recursos Naturales: La Unión de Trabajadores Desocupados de Gral. Mosconi en Argentina y la Asamblea del Pueblo Guaraní de Tarija en Bolivia. PhD Thesis, Universidad de Buenos Aires, Argentina.

Wálter Sánchez C (1998) La plaza tomada: Proceso histórico y etnogénesis musical entre los Chiriguano de Bolivia. Latin American Music Review 19(2):218-243.

Wilson A, Carlson B and Sciascia A (2017) Reterritorialising social media: Indigenous people rise up. Australasian Journal of Information Systems 21:1-4.

Wilson P and Stewart M (eds) (2008) Global Indigenous Media: Cultures, Poetics, and Politics. Durham: Duke University Press. 
Wingert S and White J (2017) Introduction to the Special Issue: Reconciling Research: Perspectives on Research Involving Indigenous Peoples. The International Indigenous Policy Journal 8(2):1-11.

Zapata DB (2017) Inayan/nga-ag and other indigenous codes: How the Applai and Bontok Igorot's indigeneity found its way into the mobile world. Telematics and Informatics 34(7):1333-1350. 